УДК 005.52:657.372.12:664.013

DOI: $10.15673 /$ fie.v10i4.1132

Купріна H.M.

кандидат економічних наук, доцент кафедра обліку та аудиту E-mail: k.natali@ukr.net

\section{Апостолов К.В.} магістрант кафедра обліку та аудиту E-mail: 0402265@mail.ru
Шаталова А.B.

магістрант кафредра обліку та аудиту

E-mail: booker.anshatl@gmail.com

Бачинська О.В.

магістрант

кафедра обліку та аудиту

Одеська національна академія харчових технологій

вул. Канатна, 112, м. Одеса, Україна, 65039

E-mail: olgabachinskaya@ukr.net

\title{
АНАЛІЗ ФІНАНСОВИХ РЕЗУЛЬТАТІВ ДІЯЛЬНОСТІ ПІДПРИЄМСТВА: ТЕОРЕТИЧНИЙ ТА ПРАКТИЧНИЙ АСПЕКТ
}

В статті проведено дослідження підходів до класифікації фінансових результатів діяльності підприємства в наукових працях та відповідно до НП(С)БО 1. Досліджено підходи до проведення економічного аналізу фінансових результатів діяльності підприємства. Показано джерела для проведення аналізу фінансових результатів: дані бухгалтерського обліку та фрінансової звітності підприємства, порядок формування яких регламентують національні положення (стандарти) обліку. Проаналізовано особливості оцінки фракторів, що впливають на зміну фінансових результатів підприємства, в дослідженні науковців. Запропонована методика економічного аналізу фінансових результатів та їх фракторний аналіз з використанням адитивної моделі для проведення багаторівневого фракторного аналізу фінансових результатів від звичайної діяльності з урахуванням сучасних напрямів та видів діяльності промислового підприємства, що підвищує якість його виконання та можливості визначення впливу значно більшої кількості фракторів.

Ключові слова: фінансові результати, прибуток, збиток, доходи, витрати, види діяльності підприємства, фракторний аналіз, адитивна фракторна модель.

This work is licensed under a Creative Commons Attribution 4.0 International License http://creativecommons.org/licenses/by/4.0/

Постановка проблеми та її зв'язок 3 важливими науковими та практичними завданнями. Фінансовий результат будь-якого підприємства $є$ найважливішим показником, який характеризує ефективність його діяльності та можливість його подальшого розвитку що дає змогу оперативно реагувати на зміни зовнішнього середовища. Величина фінансового результату створює запас фінансової стійкості. В сучасний період розвитку ринкової економіки та наявності великої кількості саме збиткових промислових підприємств формування та аналіз фінансового результату діяльності, зниження витрат та збільшення доходів, й збільшення прибутку, набуває особливої актуальності. Так, необхідність і значення аналізу фінансових результатів полягає в тому, що прибуток відображає кінцевий результат діяльності підприємства та є джерелом розширення виробництва та іншої діяльності, формування державного і місцевого бюджетів. Першочерговим завданням аналізу фінансових результатів є оцінювання їх складу, динаміки та структури та факторів, які впливають на їх формування.

Аналіз останніх публікацій по проблемі. Питанням аналізу фінансових результатів діяльності підприємства присвячені наукові праці Андрєєвої Г.I., Антонюка О.П., Базілінської О.Я., Бойчика I.М., Бо- люха М.А., Бурчевського В.3., Власюк Т.М., Гадзевича O.I., Герасима П.М., Горицької Н.Г., Журавель Г.П., Івахненко В.М., Ізмайлової К.В., Кіндрацької Г.І. , Лахтіонової Л.А., Лиференко Г.Н., Мельника В.М., Мец В.О., Мних С.В., Подольської В.О., Ступницької T.М., Тарасенка Н.В., Фролової Т.О., Цал-Цалко Ю.С., Хомин П.Я., Череп А.В., Чернелевського Л.М., Чигринської О.С., Чумаченка М.Г., Шеремет О.О., Яриш О.В. та ін., але в сучасних умовах діяльності підприємства $€$ актуальними, тому що недостатньо уваги приділяється аналізу формування, динаміки та структури фінансових результатів від саме за окремих видів діяльності підприємства та їх факторному аналізу. Ще одним аспектом актуальності дослідження $\epsilon$ й необхідність формування такого підходу, який дозволяє на промисловому підприємстві швидко та ефективно проводити такій економічний аналіз фінансових результатів для забезпечення функціонування підприємства та збільшення позитивного фінансового результату.

Формулювання цілей дослідження. Метою статті є дослідження підходів до класифікації фінансових результатів діяльності підприємства в наукових працях та відповідно до НП(С)БО 1; напрямів проведення економічного аналізу фінансових результатів 
діяльності підприємства, їх факторного аналізу та формування практичного підходу для його проведення на промисловому підприємству в сучасних умовах.

Виклад основних результатів та їх обгрунтування. Фінансові результати діяльності підприємства $\epsilon$ найважливішими показниками в системі управління підприємством. Поняття «фінансовий результат» виражається в категоріях «прибуток» та «збиток», у яких порядок формування єдиний, але є протилежним за змістом. Формування фінансових результатів методом їх порівняння передбачає застосу- ванню принципу нарахування та відповідності доходів та витрат. При здійсненні аналізу фінансових результатів основним джерелом $\epsilon$ дані обліку та фінансової звітності підприємства, а саме Форми №2 «Звіт про фінансові результати (Звіт про сукупний дохід» та Форми №5 «Примітки до річної фінансової звітності», порядок формування яких регламентує НП(С)БО 1 «Загальні вимоги до фінансової звітності» [1].

Дослідження наукових праць вчених показало, що не існує єдиного підходу до класифікації фінансових результатів діяльності підприємства (табл. $1)$.

Таблиця 1

Аналіз підходів до класифікації фінансових результатів підприсмств*

\begin{tabular}{|c|c|c|c|c|c|c|c|c|c|c|c|}
\hline \multirow[b]{2}{*}{$\begin{array}{l}\text { Класифіка- } \\
\text { ційні ознаки }\end{array}$} & \multirow[b]{2}{*}{$\begin{array}{c}\text { Класифікація } \\
\text { показників }\end{array}$} & \multicolumn{10}{|c|}{ Автори, джерело } \\
\hline & & 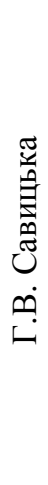 & 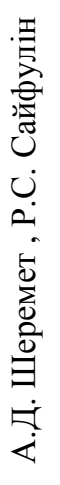 & 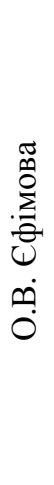 & 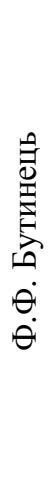 & "ִ & 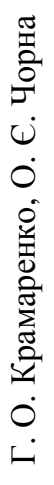 & 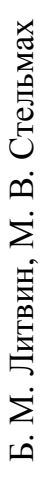 & $\sum_{\dot{U}}^{\grave{\Xi}}$ & 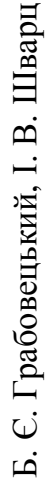 & 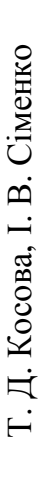 \\
\hline \multirow{6}{*}{$\begin{array}{l}\text { Аналіз складу } \\
\text { та динаміки } \\
\text { прибутку: }\end{array}$} & $\begin{array}{l}\text { Прибуток від реаліза- } \\
\text { ції продукції (товарів, } \\
\text { робіт, послуг) }\end{array}$ & + & + & + & + & + & + & + & + & + & + \\
\hline & $\begin{array}{l}\text { Маржинальний при- } \\
\text { буток }\end{array}$ & + & + & & & & & + & + & + & + \\
\hline & $\begin{array}{l}\text { Загальний фінансовий } \\
\text { результат }\end{array}$ & + & + & & + & & + & + & + & + & \\
\hline & $\begin{array}{l}\text { Поглиблений фінан- } \\
\text { совий результат }\end{array}$ & & + & + & + & & + & + & + & + & \\
\hline & $\begin{array}{l}\text { Капіталізований при- } \\
\text { буток }\end{array}$ & + & & & + & + & + & + & + & + & \\
\hline & Споживчий прибуток & + & & & + & + & + & + & + & + & \\
\hline \multirow{2}{*}{$\begin{array}{l}\text { Аналіз фінан- } \\
\text { сових резуль- } \\
\text { татів від реалі- } \\
\text { зації продукцї } \\
\text { (товарів, робіт, } \\
\text { послуг) }\end{array}$} & $\begin{array}{l}\text { Динаміка фінансових } \\
\text { результатів }\end{array}$ & + & + & & + & & & & + & + & + \\
\hline & $\begin{array}{l}\text { Виконання плану } \\
\text { прибутку від реаліза- } \\
\text { ції продукції та зміна } \\
\text { іï суми }\end{array}$ & + & & + & + & + & & & & + & \\
\hline $\begin{array}{l}\text { Аналіз цінової } \\
\text { політики підп- } \\
\text { риємства. } \\
\text { Факторний } \\
\text { аналіз рівня } \\
\text { середньо- } \\
\text { реалізованих } \\
\text { цін }\end{array}$ & $\begin{array}{l}\text { Вплив на зміну рівня } \\
\text { середньо- } \\
\text { реалізованих цін }\end{array}$ & + & + & & + & & & + & + & & \\
\hline \multirow{2}{*}{$\begin{array}{l}\text { Аналіз до- } \\
\text { ходів та ви- } \\
\text { трат всіх } \\
\text { видів діяль- } \\
\text { ності }\end{array}$} & $\begin{array}{l}\text { Склад та динаміка } \\
\text { аналізу доходів та } \\
\text { витрат }\end{array}$ & + & + & + & + & + & & + & + & + & + \\
\hline & $\begin{array}{l}\text { Фактори зміни суми } \\
\text { отриманих збитків та } \\
\text { прибутку по кожному } \\
\text { конкретному випадку }\end{array}$ & + & + & + & + & + & & + & & + & + \\
\hline
\end{tabular}




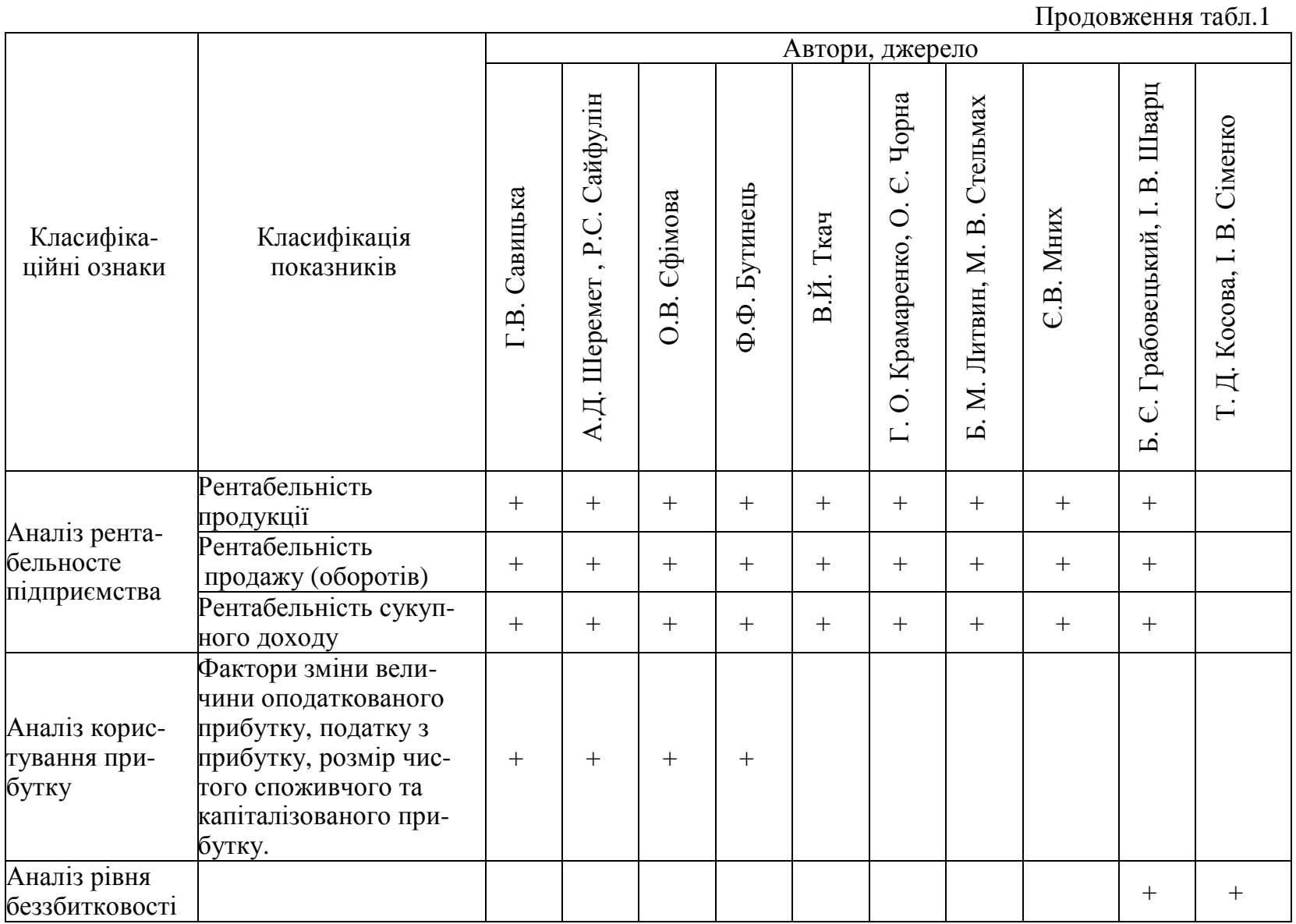

*Сформовано авторами на підставі джерел

Доходи і витрати у бухгалтерському обліку групуються за видами звичайної діяльності (операційна, фінансова, інвестиційна, інша), а також формування фінансових результатів та саме за таким підходом відображаються у формі №2 (рис. 1) [1] та $\epsilon$ найбільш зручним для аналізу формування фінансових результатів в практичної діяльності підприємства.

Дослідження підходів до аналізу фінансових результатів підприємства показало, що більшість авторів в питанні аналітичної оцінки фінансових результатів підприємства здійснюють за такими напрямками, як: оцінка рівня, динаміки й структури фінансових результатів та показників, що їх формують, тобто доходів і витрат; аналіз фінансового результату від операційної діяльності, як основної діяльності підприємства; визначення впливу основних факторів на формування фінансового результату суб'єкта господарювання та аналіз показників рентабельності (табл. 2).

Аналіз фінансового стану підприємства, за дослідженнями Петришиної Н.С. [8], є необхідним етапом для розробки планів і прогнозів фінансового оздоровлення підприємств та повинен охоплювати: горизонтальний (часовий) аналіз - порівняння кожної позиції звітності з попереднім періодом; вертикальний (структурний) аналіз - визначення структури фінансових показників з оцінкою впливу різних факторів на кінцевий результат; трендовий аналіз - порівняння кожної позиції звітності з рядом попередніх періодів та визначення тренду, тобто основної тенденції динаміки показників, очищеної від впливу інди- відуальних особливостей окремих періодів (за допомогою тренду здійснюється екстраполяція найважливіших фінансових показників на перспективний період, тобто перспективний прогнозний аналіз фінансового стану); аналіз відносних показників (коефіцієнтів) - розрахунок відношень між окремими позиціями звіту або позиціями різних форм звітності, визначення взаємозв' язків показників; порівняльний аналіз внутрішньогосподарський аналіз зведених показників звітності за окремими показниками самого підприємства та його дочірніх підприємств (філій), а також міжгосподарський аналіз показників даної фірми порівняно $з$ показниками конкурентів або із середньогалузевими та середніми показниками; факторний аналіз - визначення впливу окремих факторів (причин) на результативний показник детермінованих (розділених у часі) або стохастичних (що не мають певного порядку) прийомів дослідження. На думку Петришиної Н.С., факторний аналіз може бути як прямим «власне аналіз, коли результативний показник розділяють на окремі складові», так і зворотним «синтез, коли його окремі елементи з'єднують у загальний результативний показник» [8].

За результатами дослідження автора Яріш П.М., окрім традиційних математично-статистичних методів дослідження фінансових результатів, вчений відокремлює економічні методи, методи економічної кібернетики й оптимального програмування, методи дослідження операцій і теорії прийняття рішень. 


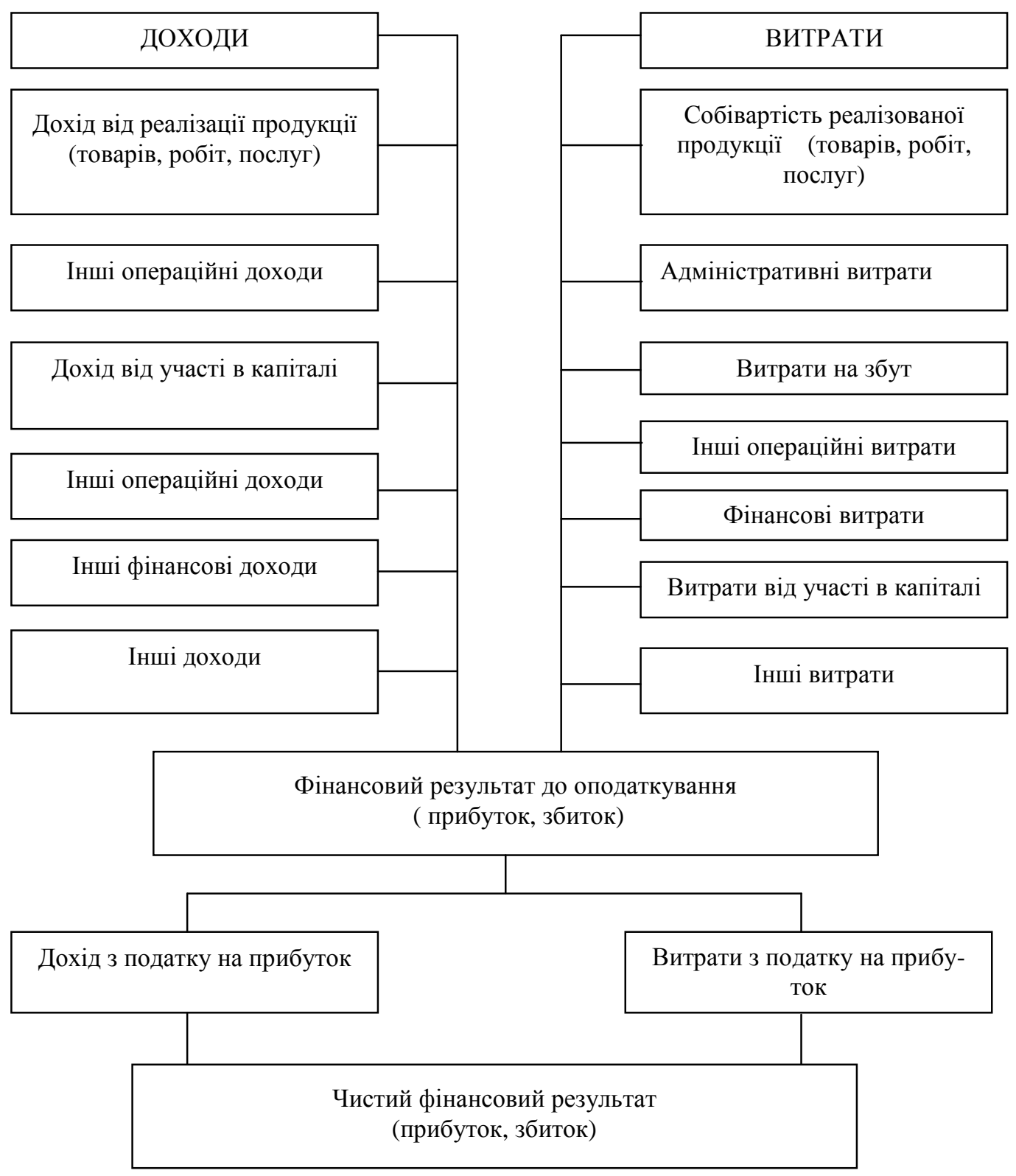

Рис. 1 - Склад доходів і витрат для формування фінансових результатів за видами діяльності [10]

Таблиця 2

Окремі підходи до аналізу фінансових результатів підприсмств*

\begin{tabular}{|l|l|}
\hline \multicolumn{1}{|c|}{ Автор, джерело } & \multicolumn{1}{|c|}{ Напрями проведення аналізу фінансових результатів } \\
\hline Мельник Т.Ю.[2] & $\begin{array}{l}\text { Вертикальний і горизонтальний та трендовий аналіз фінансових } \\
\text { результатів підприємства }\end{array}$ \\
\hline Чмутова В.П.[3, С. 66-69] & $\begin{array}{l}\text { 1. Аналіз показників фінансових результатів за видами ї діяльності } \\
\text { (операційна, фінансова, інвестиційна) в їх динаміці та їх структура. } \\
\text { 2. Фактори, які призвели до змін показни-ків фінансових результатів. }\end{array}$ \\
\hline Стаднюк Т.С.[ 4] & $\begin{array}{l}\text { 1. Аналіз доходів і витрат та рентабельності. } \\
\text { 2. Аналіз фінансових результатів. }\end{array}$ \\
\hline Яріш П.М., Касьянова Ю.В. [5] & $\begin{array}{l}\text { 1. Математико-статистичні методи дослідження фінансових результа- } \\
\text { тів: } \\
\text { економічні методи, методи економічної кібернетики й оптимального } \\
\text { програмування, методи дослідження операцій і теорії прийняття рі- } \\
\text { шень. } \\
\text { 2. СУР-аналіз і концепція фінансового важеля. }\end{array}$ \\
\hline
\end{tabular}




\begin{tabular}{|l|l|}
\multicolumn{2}{|l}{ Продовження табл.2 } \\
\hline Автор, джерело & Напрями проведення аналізу фінансових результатів \\
\hline Білик М.Д., Притуляк Н.М., Пав- & 1. Вертикальний і горизонтальний аналіз фінансових результатів \\
ловська О.В., Невмержицька М.Ю. & підприємства. \\
& 2. Факторний аналіз прибутку. \\
& 3. Аналіз показників рентабельності. \\
& 4. Факторний аналіз показників рентабельності. \\
& 5. Система «директ-кост» як теоретична база аналізу витрат та \\
& оптимізації прибутку. \\
& 6. Аналіз резервів збільшення прибутку. \\
\hline Литвин Б.М., Стельмах М.В. & 1. Оцінка динаміки й складу фінансових результатів. \\
[ 7, С. 37-80] & 2.Факторний аналіз прибутку від операційної діяльності. \\
& 3. Аналіз взаємозв’язку витрат, обсягу виробництва та прибутку. \\
\hline Петришина Н.С. & 4. Аналіз рентабельності підприємства. \\
[ 8] & 1. Вертикальний і горизонтальний та трендовий аналіз фінансових \\
& результатів підприємства. \\
\hline Мочаліна 3.М., О. В. Поспєлов [9] & 2. Аналіз відносних показників (коефіцієнтів), факторний аналіз. \\
& 1. Структурно-динамічний аналіз фінансових результатів, у тому числі \\
& доходів та витрат; \\
& 2. Факторний аналіз фінансових результатів; \\
& 3. Коефіцієнтний аналіз фінансових результатів; \\
& 4. Аналіз показників рентабельності \\
\hline
\end{tabular}

*Сформовано авторами на підставі джерел [2-9]

Для глибокої оцінки фінансових результатів та точнішого обгрунтування рекомендацій для покращення роботи підприємства також використовують CVP-аналіз і концепцію фінансового важеля [5].

На думку В.П. Чмутової. [3], при проведенні аналізу фінансових результатів доцільно використовувати величину чистого грошового потоку для розрахунку показників рентабельності, оскільки величина чистого прибутку, яка вказана в звітності, не відображає реальної суми коштів, якими може розпоряджатися підприємство, через визнання доходів і витрат незалежно від того, отримані або сплачені відповідні грошові суми.

Мочаліна 3. М. і Поспєлов О. В. побудували алгоритм проведення аналізу фінансових результатів, в основі якого лежить структурно-динамічний аналіз у поєднанні з факторним аналізом, оцінкою коефіцієнтів, аналізом показників рентабельності й інтегральним аналізом та акцентували увагу на тому, що аналіз фінансових результатів слід проводити, спочатку аналізуючи узагальнюючі показники фінансових результатів за видами їх діяльності (операційна, фінансова, інвестиційна) в їх динаміці, а далі вивчається їх структура, визначається зміна в аналізованому періоді щодо базисного періоду або до бізнес-плану; виявляються фактори, дія яких призвела до змін [9].

Попереднє дослідження підходів до аналізу фінансових результатів показало [11], що економічний аналіз фінансових результатів діяльності підприємства, на нашу думку, спрямований на вивчення їх складу, динаміки та структури не тальки в цілому по підприємству, але й за окремими видами його діяльності, на відміну від дослідження $[12$, с. $5-14 ; 13$, с. 335-340; 14, с.196-197; 15, с.367-368; 16, с.53-57;], які приділяють найбільшу увагу аналізу фінансових результатів від основної операційної діяльності, хоча на фінансовий результат діяльності підприємства значно впливають і фінансові результати від фінансової, інвестиційної та іншої діяльності підприємства. Особливе значення має саме факторний аналіз діяльності підприємства. Так, Кіндрацька Г.І., Білик М.С., Загородній А.Г., як показало дослідження проводять факторний аналіз прибутку від операційної діяльності 3 використанням адитивної факторної моделі, яка містить узагальнені фактори - «дає змогу оцінити вплив кожного із узагальнених факторів (фактори першого порядку) на зміну прибутку від операційної діяльності», а для більш глибокої деталізації факторного аналізу необхідно розкрити структуру таких факторів за рахунок факторів другого порядку - елементів витрат відповідно до П(С)БО 16 «Витрати» [15, с. 368]:

$$
\Delta \Pi_{\mathrm{o}}=\Delta Ч_{д}-\Delta \mathrm{C}_{\mathrm{p}}+\Delta \mathrm{LO}_{\mathrm{i}}-\Delta \mathrm{B}_{\mathrm{a}}-\Delta \mathrm{B}_{3}-\Delta \mathrm{BO}_{\mathrm{i}}
$$

де $\Delta \Pi_{о}$ - зміна абсолютної величини прибутку від операційної діяльності підприємства у звітному періоді порівняно з базовим (попереднім чи плановим) показником; $\Delta$ Чд - зміни абсолютної величини чистого доходу; $\Delta \mathrm{C}_{\mathrm{p}}-$ зміни собівартості реалізованої продукції (товарів, робіт, послуг); $\Delta$ ДО ших операційних доходів; $\Delta \mathrm{B}_{\mathrm{a}}-$ зміни адміністративних витрат; $\Delta \mathrm{B}_{3}-$ зміни витрат на збут; $\Delta \mathrm{BO}_{\mathrm{i}}-$ зміни інших операційних витрат.

На нашу думку [17], факторний аналіз фінансових результатів діяльності промислового підприємства повинен охоплювати не тільки результат від операційної діяльності (основної та іншої), але й від фінансової, інвестиційної, іншої, тобто від усіх видів звичайної діяльності, так як прибуток або збиток від даних видів діяльності підприємства здійснює суттєвий вплив на загальний фінансовий результат.

Проведене попереднє дослідження показало, що для проведення багаторівневого факторного ана- 
аналізу фінансових результатів від звичайної діяльності з використанням методики побудови адитивної моделі необхідно застосовувати фактори [17]:

- першого порядку (відповідні доходи та витрати від певного виду звичайної діяльності);

- другого порядку (деталізація факторів першого порядку: доходів та витрат від певного виду звичайної діяльності (наприклад, витрати від операційної діяльності поділяються на собівартість реалізованої продукції (товарів, робіт, послуг), адміністративні витрати, витрати на збут);

- третього порядку (деталізація факторів другого порядку: доходів та витрат за окремими статями або їх деталізацією - наприклад, собівартість реалізованої продукції (товарів, робіт, послуг) на матеріальні витрати, витрати на оплату праці, амортизація тощо).
Таким чином, для ефективного управління доходами, витратами та фінансовими результатами аналіз фінансових результатів для промислового підприємства повинен охоплювати: аналіз складу, динаміки та структури фінансових результатів; аналіз формування та динаміки фінансових результатів підприємства від основної операційної діяльності; детальний аналіз формування, динаміки та структури фінансових результатів від іншої операційної діяльності; аналіз формування чистого прибутку; аналіз рентабельності виробництва; для виявлення та усунення негативних факторів та збільшення впливу позитивних, проводити факторний аналіз фінансових результатів діяльності підприємства за допомогою використання їх адитивної моделі (табл. 3).

Таблиця 3

Факторний аналіз фінансових результатів від звичайної діяльності підприємства за абсолютними показниками*

\begin{tabular}{|c|c|c|c|c|c|c|}
\hline \multirow[t]{2}{*}{ Показники } & \multirow{2}{*}{$\begin{array}{l}\text { Попередній } \\
\text { рік, } \\
\text { тис. грн. }\end{array}$} & \multirow{2}{*}{$\begin{array}{l}\text { Звітний } \\
\text { рік, } \\
\text { тис. грн. }\end{array}$} & \multicolumn{2}{|c|}{ Відхилення } & \multicolumn{2}{|c|}{$\begin{array}{c}\text { Вплив факторів на зміну } \\
\text { фінансових результатів, } \\
\text { тис. грн. }\end{array}$} \\
\hline & & & тис. грн. & $\%$ & $\begin{array}{c}\text { зміна } \\
\text { доходу }\end{array}$ & $\begin{array}{l}\text { зміна } \\
\text { витрат }\end{array}$ \\
\hline $\begin{array}{l}\text { 1. Фінансовий результат від } \\
\text { основної операційної діяль- } \\
\text { ності }\end{array}$ & -7976 & -14040 & -6064 & 76,0 & -47393 & 41329 \\
\hline $\begin{array}{l}\text { 2. Доход від основної опера- } \\
\text { ційної діяльності }\end{array}$ & 95549 & 48156 & -47393 & $-49,6$ & -47393 & $\mathrm{x}$ \\
\hline $\begin{array}{l}\text { 3. Витрати від основної опера- } \\
\text { ційної діяльності }\end{array}$ & 103525 & 62196 & -41329 & $-39,9$ & $\mathrm{x}$ & 41329 \\
\hline $\begin{array}{l}\text { 4. Фінансовий результат від } \\
\text { іншої операційної діяльності }\end{array}$ & -7782 & -1196 & 6586 & $-84,6$ & -1971 & 8557 \\
\hline $\begin{array}{l}\text { 5. Доход від іншої операційної } \\
\text { діяльності }\end{array}$ & 4486 & 2515 & -1971 & $-43,9$ & -1971 & $\mathrm{x}$ \\
\hline $\begin{array}{l}\text { 6. Витрати від іншої операцій- } \\
\text { ної діяльності }\end{array}$ & 12268 & 3711 & -8557 & $-69,75$ & $\mathrm{x}$ & 8557 \\
\hline $\begin{array}{l}\text { 7. Фінансовий результат від } \\
\text { фінансової діяльності }\end{array}$ & - & - & - & $\mathbf{x}$ & - & - \\
\hline $\begin{array}{l}\text { 8. Доход від фінансової діяль- } \\
\text { ності }\end{array}$ & - & - & - & - & - & $\mathrm{x}$ \\
\hline $\begin{array}{l}\text { 9. Витрати від фінансової дія- } \\
\text { льності }\end{array}$ & - & - & - & - & $\mathrm{x}$ & - \\
\hline $\begin{array}{l}\text { 10. Фінансовий результат від } \\
\text { інвестиційної діяльності }\end{array}$ & - & - & - & - & - & - \\
\hline 11. Доходи від участі в капіталі & - & - & - & - & - & - \\
\hline 12. Втрати від участі в капіталі & - & - & - & - & - & - \\
\hline $\begin{array}{l}\text { 13. Фінансовий результат від } \\
\text { іншої діяльності }\end{array}$ & -9 & -61 & -52 & в 5,8 p. & - & -52 \\
\hline 14. Доходи від іншої діяльності & - & - & - & - & - & $\mathrm{x}$ \\
\hline 15.Витрати від іншої діяльності & 9 & 61 & 52 & в 5,8 p. & $\mathrm{x}$ & -52 \\
\hline $\begin{array}{l}\text { 16. Фінансовий результат від } \\
\text { звичайної діяльності до опо- } \\
\text { даткування }\end{array}$ & -15767 & -15297 & 470 & -3 & -49364 & 49834 \\
\hline $\begin{array}{l}\text { 17. Доходи від звичайної дія- } \\
\text { льності до оподаткування, в } \\
\text { т.ч. }\end{array}$ & 100035 & 50671 & -49364 & 49,3 & -49364 & $\mathrm{x}$ \\
\hline $\begin{array}{l}\text { - від основної операційної } \\
\text { діяльності }\end{array}$ & 95549 & 48156 & -47393 & $-49,6$ & -47393 & $\mathrm{x}$ \\
\hline
\end{tabular}


Продовження табл.3

\begin{tabular}{|c|c|c|c|c|c|c|}
\hline \multirow[t]{2}{*}{ Показники } & \multirow{2}{*}{$\begin{array}{c}\text { Попередній } \\
\text { рік, } \\
\text { тис. грн. }\end{array}$} & \multirow{2}{*}{$\begin{array}{l}\text { Звітний } \\
\text { рік, } \\
\text { тис. грн. }\end{array}$} & \multicolumn{2}{|c|}{ Відхилення } & \multicolumn{2}{|c|}{$\begin{array}{c}\text { Вплив факторів на змі- } \\
\text { ну фінансових резуль- } \\
\text { татів, тис. грн. } \\
\end{array}$} \\
\hline & & & тис. грн. & $\%$ & $\begin{array}{c}\text { зміна } \\
\text { доходу }\end{array}$ & $\begin{array}{c}\text { зміна } \\
\text { витрат }\end{array}$ \\
\hline $\begin{array}{l}\text { - від іншої операційної діяль- } \\
\text { ності }\end{array}$ & 4486 & 2515 & -1971 & $-43,9$ & -1971 & $\mathrm{x}$ \\
\hline - від фінансової діяльності & $\mathrm{x}$ & $\mathrm{x}$ & $\mathrm{x}$ & $\mathrm{x}$ & - & $\mathrm{x}$ \\
\hline - від іншої діяльності & $\mathrm{x}$ & $\mathrm{x}$ & $\mathrm{x}$ & $\mathrm{x}$ & - & $\mathrm{x}$ \\
\hline $\begin{array}{l}\text { 18. Витрати від звичайної дія- } \\
\text { льності до оподаткування, в } \\
\text { т.ч. }\end{array}$ & 115802 & 65968 & -49834 & $-43,0$ & $\mathrm{x}$ & 49834 \\
\hline $\begin{array}{l}\text { - від основної операційної } \\
\text { діяльності }\end{array}$ & 103525 & 62196 & -41329 & $-39,9$ & $\mathrm{x}$ & 41329 \\
\hline $\begin{array}{l}\text { - від іншої операційної діяль- } \\
\text { ності }\end{array}$ & 12268 & 3711 & -8557 & $-69,75$ & $\mathrm{x}$ & 8557 \\
\hline - від фінансової діяльності & $\mathrm{x}$ & $\mathrm{x}$ & $\mathrm{x}$ & $\mathrm{x}$ & $\mathrm{x}$ & $\mathrm{x}$ \\
\hline - від іншої діяльності & 9 & 61 & 52 & в $5,8 \mathrm{p}$. & $\mathrm{x}$ & -52 \\
\hline
\end{tabular}

*розраховано авторами на підставі джерела [17]

Висновки та перспективи подальших досліджень. Проведене дослідження показало, що:

- фінансові результати діяльності підприємства $€$ найважливішими показниками в системі управління підприємством, визначення і порядок формування яких для фінансового обліку та економічного аналізу регламентує НП(С)БО 1 «Загальні вимоги до фінансової звітності», але дослідження наукових праць вчених показало, що не існує єдиного підходу до класифікації фінансових результатів діяльності підприємства;

- доходи і витрати у бухгалтерському обліку групуються за видами звичайної діяльності, а також формування фінансових результатів та саме за таким підходом відображаються у формі №2 та $є$ найбільш зручним для аналізу формування фінансових результатів в практичної діяльності підприємства;

- більшість авторів проводять оцінку факторів, які впливають на зміну фінансових результатів тільки від основної операційної або операційної діяльності, що значно обмежує можливості такого аналізу;
- для ефективного управління доходами, витратами та фінансовими результатами аналіз фінансових результатів для промислового підприємства повинен охоплювати: аналіз складу, динаміки та структури фінансових результатів; аналіз формування та динаміки фінансових результатів підприємства від основної операційної діяльності; детальний аналіз формування, динаміки та структури фінансових результатів від іншої операційної діяльності; аналіз формування чистого прибутку; аналіз рентабельності виробництва; для виявлення та усунення негативних факторів та збільшення впливу позитивних, проводити факторний аналіз фінансових результатів діяльності підприємства за допомогою використання їх адитивної моделі

- використання адитивної моделі для проведення багаторівневого факторного аналізу фінансових результатів від звичайної діяльності підвищує якість його виконання та можливості визначення значно більшої кількості факторів.

\section{Література}

1. Загальні вимоги до фінансової звітності: Національне положення (стандарт) бухгалтерського обліку 1: затв. наказом Мінфіну від 07.02.2013 №73 за станом на 03.08.2018 p. URL: http://zakon.rada.gov.ua/laws/show/z0336-13 (дата звернення: 11.09.2018).

2. Мельник Т.Ю. Формування інформаційних ресурсів управлінського обліку для контролювання фінансових результатів підприємства // Молодий вчений. 2015. № 8 (23). Ч. 2. С. 63-68.

3. Чмутова В. П. Методические подходы к статистической оценке финансовых результатов деятельности предприятия // Вісник. 2001. № 1(17). С. 66-69.

4. Стаднюк Т.С. Особливості методики аналізу фінансових результатів діяльності підприємств // Економічний часопис Східноєвропейського національного університету імені Лесі Українки. 2016. № 1. С. 127132.

5. Яріш П.М., Касьянова Ю. В. Методи проведення аналізу фінансових результатів діяльності організацій // Управління розвитком. 2015. № 4(144). С. 159-162.

6. Білик М. Д., Павловська О. В., Н. М. Притуляк, Н. Ю. Невмержицька Фінансовий аналіз: навч. посібник / Білик М. Д. та ін. 2-ге вид. К.: КНЕУ, 2014. 592 с. 
7. Литвин Б.М., Стельмах М.В. Фінансовий аналіз: навч.посібник. К. : «Хай-Тек Прес», 2013. 336 с.

8. Петришина Н.С., Кнець Ю.О. Методичні основи аналізу фінансових результатів діяльності промислового підприємства // Наука й економіка. 2014. № 2 (34). С. 52-54.

9. Мочаліна 3.М. Поспєлов О.В. Методичний інструментарій та сучасні проблеми аналізу фінансових результатів // Науково-технічний збірник «Комунальне господарство міст». 2011. № 98. С. 221-227.

10. Білик М.Д., Бабіч В.В. Обліково-аналітичне забезпечення управління фінансовими результатами діяльності підприємств // Бізнес Інформ. 2015. № 4. С. 207.

11. Купріна Н.М., Терепенчук В.В. Особливості економічного аналізу фінансових результатів діяльності промислового підприємства // Науковий вісник. Науки: економіка, політологія, історія. 2010. С. 91-100.

12. Гадзевич О.І. Основи економічного аналізу і діагностики фінансово-господарської діяльності підприємства: навч. посібник. К.: Кондор, 2007. 180 с.

13. Герасим П.М., Журавель Г.П., Хомин П.Я. Фінансовий, управлінський і податковий облік у господарських товариствах (ВАТ, ЗАТ, ТОВ, ПОП, ПАП): навчальний посібник. Тернопіль, 2003. 522 с.

14. Горицкая Н.Г. Особенности бухгалтерського учета в современных условиях: навч. посібник. К.: Редакция газеты «Бухгалтерия. Налоги. Бизнес», 2002. - 352 с.

15. Кіндрацька Г.І., Білик М.С., Загородній А.Г. Економічний аналіз: підручник / за ред. проф. А.Г. Загороднього. 3-е вид. переробл. та допов. К. : Знання, 2008. 487 с.

16. Шеремет О.О. Фінансовий аналіз: навч. посібник. К.: Кондор, 2005. 196 с.

17. Купріна Н.М., Терепенчук В.В. Факторний аналіз фінансових результатів від звичайної діяльності промислового підприємства // Економіка: проблеми теорії та практики: зб. наук.пр. Дніпропетровськ: ДНУ. 2010. Вип. 266. Т.1. С. 25-36.

Стаття надійшла 05.10.2018 Стаття прийнята до друку 19.10.2018 Доступно в мережі Internet 29.12.2018

\author{
Куприна Н.M. \\ кандидат экономических наук, доцент \\ кафедра учета и аудита \\ E-mail: k.natali@ukr.net
}

Апостолов К.В. кафедра учета и аудита E-mail:0402265@mail.ru

\section{Шаталова А.B.} магистрант кафедра учета и аудита E-mail: booker.anshatl@gmail.com

Бачинская О.В. магистрант кафредра учета и аудита

Одесская национальная академия пищевых технологий ул. Канатная, 112, г. Одесса, Украина, 65039

E-mail: olgabachinskaya@ukr.net

\section{АНАЛИЗ ФИНАНСОВЫХ РЕЗУЛЬТАТОВ ДЕЯТЕЛЬНОСТИ ПРЕДПРИЯТИЯ: ТЕОРЕТИЧЕСКИЕ И ПРАКТИЧЕСКИЕ АСПЕКТЫ}

Основной целью исследования является анализ подходов к классификации финансовых результатов деятельности предприятия в научных трудах и в соответствии с НП(С)БУ 1 , направлений проведения экономического анализа финансовых результатов деятельности предприятия, их фракторного анализа и формирования практического подхода для его проведения на промышленном предприятии в современных условиях.

Проведенное исследование показало, что финансовые результаты деятельности предприятия являются важнейшими показателями в системе управления предприятием, определения и порядок формирования которых для финансового учета и экономического анализа регламентирует НП(С)БУ 1 «Общие требования к финансовой отчетности», но исследования научных публикаций ученых показало, что не существует единого подхода к классификации финнансовых результатов деятельности предприятия. Доходы и расходы в бухгалтерском учете группируются по видам обычной деятельности, а также формирования финансовых результатов осуществляется за таким подходом в форме №2 и является наиболее удобным для анализа формирования финансовых результатов в практической деятельности предприятия. Большинство авторов проводят оценку факторов, влияющих на изменение финансовых результатов только от основной операционной или операционной деятельности, что значительно ограничивает возможности такого анализа. Для эффективного управления доходами, затратами и финансовыми результатами анализ финансовых результатов для промышленного предприятия должен включать: анализ состава, динамики и 
структуры фринансовых результатов; анализ формирования и динамики финансовых результатов предприятия от основной операционной деятельности; детальный анализ формирования, динамики и структуры финансовых результатов от прочей операционной деятельности; анализ формирования чистой прибыли; анализ рентабельности производства; для выявления и устранения негативных фракторов и увеличения влияния положительных, проведение факторного анализа фринансовых результатов деятельности предприятия за счет использования аддитивной модели. Использование аддитивной модели для проведения многоуровневого фракторного анализа финансовых результатов от обычной деятельности повышает качество его выполнения и возможности определения значительно большего числа факторов.

Ключевые слова: финансовые результаты, прибыль, убыток, доходы, расходы, виды деятельности предприятия, факторный анализ, аддитивная фракторная модель.

\author{
Kuprina N. \\ Ph.D., Associate Professor \\ Department of Accounting and Auditing \\ E-mail:k.natali@@ukr.net \\ Apostolov K. \\ Undergraduate \\ Department of Accounting and Auditing \\ E-mail: 0402265@mail.ru
}

\author{
Shatalova A. \\ Department of Accounting and Auditing \\ E-mail: booker.anshatl@gmail.com \\ Bachynska 0. \\ Undergraduate \\ Department of Accounting and Auditing \\ Odessa National Academy of Food Technologies \\ Kanatna str., 112, Odesa, Ukraine, 65039 \\ E-mail: olgabachinskaya@ukr.net
}

\section{THE ANALYSIS OF THE FINANCIAL RESULTS OF THE ENTERPRISE ACTIVITY: THEORETICAL AND PRACTICAL ASPECTS}

The main purpose of the study is to analyze the approaches to the classification of the financial results of the enterprise in scientific works and in accordance with the NP (C)BO 1; directions of carrying out of the economic analysis of financial results of the enterprise activity, their factor analysis and formation of a practical approach for its holding at an industrial enterprise in modern conditions.

The conducted research showed that: financial results of the enterprise are the most important indicators in the management system of the enterprise, the definition and order of formation of which for financial accounting and economic analysis regulates NP(C)BO 1 "General requirements for financial reporting", but the research of the scientists scientific papers showed, that there is no single approach to the classification of the financial results of the enterprise. Income and expenses in the accounting are grouped by types of ordinary activities, as well as the formation of the financial results, and in this way are reflected in the form number 2 and is the most convenient for analyzing the formation of the financial results in the practical activities of the enterprise. Most authors evaluate the factors that affect the change in the financial results only from the main operating or operational activities, which significantly limits the scope of such analysis. For efficient management of income, expenses and the financial results, the analysis of the financial results for an industrial enterprise should include: the analysis of composition, dynamics and structure of the financial results; the analysis of formation and dynamics of the financial results of the enterprise from the main operational activity; the detailed analysis of the formation, dynamics and structure of the financial results from other operational activities; the analysis of the formation of net profit; the analysis of profitability of production; to identify and eliminate negative factors and increase the influence of positive ones, to conduct a factor analysis of the financial results of the enterprise through the use of their additive model. Using the additive model for the multilevel factor analysis of the financial results from ordinary activities increases the quality of its implementation and the ability to identify a much larger number of factors.

Key words: financial results, profit, loss, incomes, expenses, types of enterprise activity, factor analysis, additive factor model.

\section{References}

1. Zagal'nì vimogi do fìnansovoï zvìtnostì: Nacìonal'ne položennâ (standart) buhgalters'kogo oblìku 1: Zatv. nakazom Mìnfìnu vìd 07.02.2013 №73 za stanom na 03.08.2018 r. (2018). Retrieved September 11, 2018, from http://zakon.rada.gov.ua/laws/show/z0336-13.

2. Melnyk, T. Yu. (2015). Formuvannâ ìnformacìjnih resursìv upravlìns'kogo oblìku dlâ kontrolûvannâ fìnansovih rezul'tatìv pìdpriêmstva. Molodij Včenij, (8 (23)), 2nd ser., 63-68. 
3. Chmutova, V. P. (2001). Metodičeskie podhody k statističeskoj ocenke finansovyh rezul'tatov deâtel'nosti predpriâtiâ. Visnik, (1 (17)), 66-69.

4. Stadniuk, T. S. (2016). Osoblivostì metodiki analìzu fìnansovih rezul'tatìv dial'nostì pìdpriêmstv. Ekonomičnij časopis Shidnoêvropejs'kogo Nacional'nogo Unìversitetu ìmenì Lesi Ukrainky, (1), $127-132$.

5. Yarish, P. M., \& Kasianova, Yu. V. (2015). Metodi provedennâ analìzu fìnansovih rezul'tatìv diâl'nostì organìzacìj. Upravlinnâ Rozvitkom, (4 (144)), 159-162.

6. Bilyk, M. D., Pavlovska, O. V., Prytuliak, N. M., \& Nevmerzhytska, N. Yu. (2014). Fìnansovij analiz (2nd ed.). Kyiv: KNEU.

7. Lytvyn, B. M., \& Stelmakh, M. V. (2013). Finansovij analiz. Kyiv: «Haj-Tek Pres».

8. Petryshyna, N. S., \& Knets, Yu. O. (2014). Metodičnì osnovi analìzu fînansovih rezul'tatìv diâl'nostì promislovogo pìdpriêmstva. Nauka J Ekonomika, (2 (34)), 52-54.

9. Mochalina, Z. M., \& Pospielov, O. V. (2011). Metodičnij ìnstrumentarìj ta sučasnì problemi analìzu fìnansovih rezul'tatìv. Naukovo-tehničnij Zbirnik «Komunal'ne Gospodarstvo Mist», (98), 221-227.

10. Bilyk, M. D., \& Babich, V. V. (2015). Oblìkovo-analìtične zabezpečennâ upravlìnnâ fìnansovimi rezul'tatami diâl'nostì pìdpriêmstv. Bìnes İnform,(4), 207.

11. Kuprina, N. M., \& Terepenchuk, V. V. (2010). Osoblivostì ekonomìcnogo analìzu fìnansovih rezul'tatìv diâl'nostì promislovogo pìdpriêmstva. Naukovij Visnik. Nauki: Ekonomika, Politologiâ, ìstoriâ, 91-100.

12. Hadzevych, O. I. (2007). Osnovi ekonomičnogo analizu ì diagnostiki finansovo-gospodars'kö̈ diâl'nostì pidpriêmstva. Kyiv: Kondor.

13. Herasym, P. M., Zhuravel, H. P., \& Khomyn, P. Ya. (2003). Finansovij, upravlins'kij i podatkovij oblik u gospodars'kih tovaristvah (VAT, ZAT, TOV, POP, PAP). Ternopil.

14. Goritskaya, N. G. (2002). Osobennosti buhgalters'kogo učeta v sovremennyh usloviâh. Kyiv: Redakciâ gazety «Buhgalteriâ. Nalogi. Biznes».

15. Kindratska, H. I., Bilyk, M. S., \& Zahorodnii, A. H. (2008). Ekonomičnij analiz(3rd ed.) (A. H. Zahorodnii, Ed.). Kyiv: Znannia.

16. Sheremet, O. O. (2005). Finansovij analiz. Kyiv: Kondor.

17. Kuprina, N. M., \& Terepenchuk, V. V. (2010). Faktornij analìz fìnansovih rezul'tatìv vìd zvičajnoï diâl'nostì promislovogo pìdpriêmstva. Ekonomika: Problemi Teorï Ta Praktiki: Zb. Nauk.pr. Dnipropetrovs'k: DNU, 1(266), 25-36.

Received 2 October 2018

Approved 16 October 2018

Available in Internet 29.12.2018

Цитування згідно ДСТУ 8302:2015

Купріна Н.М., Шаталова А.В., Апостолов К.В., Бачинська О.В. Аналіз фінансових результатів діяльності підприсмства: теоретичний та практичний аспект // Економіка харчової промисловості. 2018. Т. 10, Вип. 4. С. $48-57$. doi: 10.15673/fie.v10i4.1132

Cite as APA style citation

Kuprina N., Shatalova A., Apostolov K., \& Bachynska O. (2018). The analysis of the financial results of the enterprise activity: theoretical and practical aspects. Food Industry Economics, 10(4), 48-57; doi: 10.15673/fie.v10i4.1132 